76 巻 771 号 $(2010-11)$

\title{
差分格子ボルツマン法によるトンネル圧縮波の発生と伝播計算*
}

\author{
赤 松 克 児*1, 蔦 原 道 久*2
}

\section{Numerical Simulation of Compression Wave Generation and Distortion in a Tunnel by the Lattice Boltzmann Method}

\author{
Katsuji AKAMATSU and Michihisa TSUTAHARA*3 \\ ${ }^{* 3}$ Graduate School of Engineering, Kobe University, \\ 1-1 Rokkodai, Nada-ku, Kobe-shi, Hyogo, 657-8501 Japan
}

\begin{abstract}
Direct numerical simulation of compression wave produced when a high-speed train enters a tunnel, distortion of the compression wave front as it travels in the tunnel, radiation of micropressure wave from the tunnel exit are performed using the finite difference lattice Boltzmann method. The discrete Boltzmann equation for the $3 \mathrm{D} 39 \mathrm{Q}$ thermal BGK model is solved in threedimensional space using a second-order Runge-Kutta scheme in time and a third-order-upwind finite difference scheme in space. The arbitrary Lagrangian-Eulerian formulation. (ALE) is applied to model the interaction of the moving train nose and the tunnel portal. Detailed numerical calculations were carried out for axisymmetric trains with the blockage of 0.2 and various nose profiles entering a long circular cylindrical tunnel with straight and stepwise flared portals. The predicted compression wave profiles are found to be in good agreement with linear theory predictions obtained from the analytic expression derived by Howe. It is shown that the distortion of the compression wave front is consistent with the time-domain computation of one-dimensional Burgers equation. Longer nose profiles and tunnel entrance with flared portals are confirmed not only to decrease the initial steepness of the compression wave front but also to counteract the effect of nonlinear steepening.
\end{abstract}

Key Words : Lattice Boltzmann Method, High Speed Train, Compression Wave, Micro-Pressure Wave, Nonlinear Steepening, Aerodynamic Noise, Numerical Simulation

\section{1. 緒言}

新幹線などの高速列車がトンネルに突入するとき， 車体のピストン作用により圧縮波が発生しトンネル内 を音速で伝播する。この圧縮波はトンネル出口で反射 して膨張波として返ってくるが，そのエネルギーの一 部は微気圧波と呼ばれるパルス状の音波としてトンネ ル外に放射され，低周波公害問題の原因になる ${ }^{(1)(2)}$ (図 1).

微気圧波の強度はトンネル出口に到達する圧縮波の 立ち上がりの鋭さ，すなわち波面の圧力勾配に比例す ることが知られている(2). 圧縮波波面の圧力勾配は列 車のノーズ形状, トンネル入口形状, 列車速度などに よって決まるが, 伝播過程での音響的非線形作用によ りトンネル内で勾配が増加する。その結果, 音響的に 滑らかで有限振幅音波の衝撃波形成距離と同程度の長 大トンネルでは，圧縮波は衝撃波になり，微気王波は ソニックブームなみの強さの衝撃音となることがあ る、また，衝撃波形成距離より長いトンネルや音響減

* 原稿受付 2010 年 4 月 12 日.

*1 正負, 神戸大学大学院工学研究科(画657-0015 神戸市灘区 六甲台町 1-1)

*2 正員, フェロ一, 神戸大学大学院工学研究科.

E-mail : tutahara@mech.kobe-u.ac.jp
衰作用の大きいスラブ軌道トンネルでは，一度形成さ れた衝撃波がエネルギー逸散によりトンネル出口に到 達するまでに消滅し，微気圧波の強度は低減するとの 調查報告がある(3).

このようにトンネル压縮波の発生と伝播および微気 圧波の放射は流体と音響の要因が関係する複雑な現象 であり，現象解明のために現地測定 ${ }^{(1) \sim(3)}$, 模型実験(4), 理論解析 ${ }^{(5) \sim(9)}$, 数值計算(3)(10)(11) などによる多くの研 究が行われている.Howe $\mathrm{e}^{(8)(9)}$ は列車ノーズの断面積 が変化する部分に単極子，双極子音源を分布させてト ンネル入口近くの圧縮波を計算する近似線形理論式を 導いている．福田 ${ }^{(3)}$ ，真下(10)，宮地(11) はトンネル壁の 摩擦を考慮した一次元圧縮性流体の運動方程式の数値 解析により圧縮波の伝播計算を行っている。しかしな

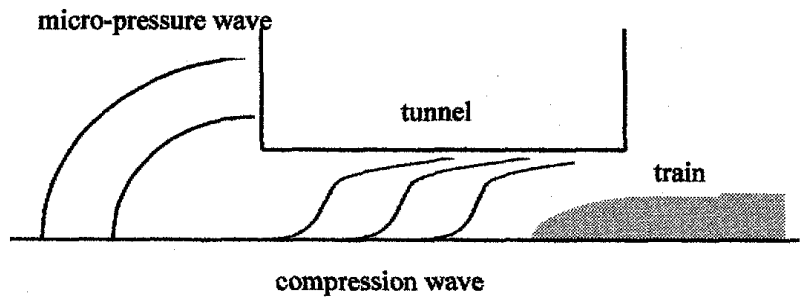

Fig. 1 Compression wave and radiation of micro-pressure wave 
がらここれらの研究では圧縮波の発生とトンネル内伝 播を個別のテーマとして取り上げており全体として解 析した報告はない. 本研究では格子ボルツマン法によ る数值計算を行い，列車ノーズ形状，列車速度，トン ネル入口形状, トンネル長さなどの要因と圧縮波の発 生と伝播特性の関係を総合的に解明する。

格子ボルツマン法 (LBM) は離散的な速度分布をも つ流体粒子の分布関数の時間発展を計算することによ り流体の運動をシミュレーションするもので，数值流 体音響分野に扔けるDNSへの適用が有望視されてい る ${ }^{(12)}$. 穒原らは円柱, 角柱, 回転翼などの物体と流体 の干渉による放射音の DNS 計算 ${ }^{(13) \sim(15)}$ や有限振幅音 波の非線形伝播特性の計算結果(16)を報告している.

本報告では差分格子ボルツマン法にALE 法(Arbitrary Lagrangian Eulerian formulation)(17) を組み合 わせて，一定速度でトンネルに突入する列車から発生 する圧縮波の圧力を計算し，トンネル入口付近の初期 波形について Howe の近似線形理論による計算値と 比較する. 伝播過程での波形の変形については一次元 Burgers 方程式の数值解により検証する。また, 列車 ノーズ長の増加やトンネル入口断面の拡大などが初期 圧力勾配の低減と伝播過程氾扔ける波面の急峻化防止 に有効であることを示す。

\section{2. 計 算 方 法}

$2 \cdot 1$ 計算式 ALE 法は移動境界を有する計算領 域に適用される手法で, 移動物体を含む格子はラグラ ンジェ的に扱われるが, 流れ場はオイラー的に表され る. ALE ボルツマン方程式は粒子の移流速度を格子 の移動速度との相対速度で置き換えた次式で表され $ろ^{(18)}$.

$$
\begin{aligned}
& \frac{\partial f_{i}}{\partial t}\left(c_{i \alpha}-V_{\alpha}\right) \frac{\partial f_{i}}{\partial x_{\alpha}}-\frac{A}{\phi} c_{i \alpha} \frac{\partial\left(f_{i}-f_{i}^{\mathrm{eq}}\right)}{\partial x_{\alpha}} \\
& =-\frac{1}{\phi}\left(f_{i}-f_{i}^{\mathrm{eq}}\right)
\end{aligned}
$$

ここで $f_{i}$ は速度分布関数, $f_{i}^{\mathrm{eq}}$ は局所平衡分布関数, $c_{i \alpha}$ は粒子速度, $V_{\alpha}$ は格子移動速度で列車速度 $U$ に 対応する。 $\phi$ は単一時間緩和係数, 添字 $i$ は粒子の種 類, $\alpha$ は空間座標 $(x, y, z)$ を表す. 左辺第 3 項は計 算を高速に行うための付加項で, $A$ は正の定数であ る. 本研究では図 2 の粒子速度ベクトルを有する 3 次 元 39 速度粒子分布モデルを用いて計算を行う。

流体の密度, 運動量, エネルギーは次式の上うに速 度分布関数の全粒子に対するモーメント和で与えられ る.

$$
\rho=\sum_{i} f_{i}
$$

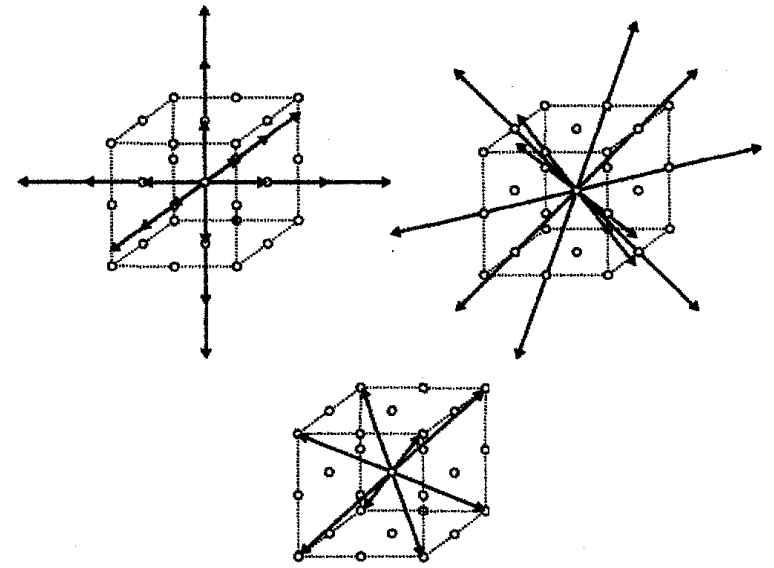

Fig. 2 Discrete velocity vectors for D3Q39 model ${ }^{(19)}$

$$
\begin{aligned}
& \rho u_{a}=\sum_{i} f_{i} c_{i \alpha} \\
& \frac{1}{2} \rho u^{2}+\rho e=\sum_{i} \frac{1}{2} f_{i} C_{i \alpha}^{2}
\end{aligned}
$$

$e$ は内部エネルギーである. 局所平衡分布関数は流体 が平衡状態住したときの粒子速度分布で, 局所的な 流体密度, 流速, 温度によって一意的に決定され, 流 速の 3 次まで考慮した次式が用いられる.

$$
\begin{aligned}
f_{i}^{\mathrm{eq}} & =F_{i} \rho\left[1-2 B c_{i \alpha} u_{\alpha}+2 B^{2}\left(c_{i \alpha} u_{\alpha}\right)^{2}\right. \\
& \left.-\frac{4}{3} B^{3}\left(c_{i \alpha} u_{\alpha}\right)^{3}+B u_{\alpha}^{2}-2 B^{2} c_{i \alpha} u_{\alpha} u_{\beta}^{2}\right]
\end{aligned}
$$

$B=-3 /(4 e), F_{i}$ は $B$ と粒子速度 $c_{i \alpha}$ の関数として 与光られる係数である(19). 圧力と音速は次式より求 められる。

$$
\begin{aligned}
& p=\frac{2}{3} \rho e \\
& c_{s}=\sqrt{\frac{10}{9} e}
\end{aligned}
$$

$2 \cdot 2$ 離散化式と計算手順 式(1)の時間微分項 に 2 次のルンゲ・クッタ法を適用すると $n+1 / 2, n$ +1 ステップの速度分布関数は次式で表される.

$$
\begin{aligned}
& f_{i}^{n+(1 / 2)}=f_{i}^{n}+\frac{1}{2} \Delta t\left[-\left(c_{i \alpha}-V_{\alpha}\right) \frac{\partial f_{i}^{n}}{\partial x_{\alpha}}\right. \\
& \left.+\sigma c_{i \alpha} \frac{\partial\left(f_{i}^{n}-f_{i}^{n, \mathrm{eq}}\right)}{\partial x_{\alpha}}-\frac{1}{\varepsilon}\left(f_{i}^{n}-f_{i}^{n, \mathrm{eq}}\right)\right] \\
& f_{i}^{n+1}=f_{i}^{n}+\Delta t\left[-\left(c_{i \alpha}-V_{\alpha}\right) \frac{\partial f_{i}^{n+(1 / 2)}}{\partial x_{\alpha}}\right. \\
& +\sigma c_{i \alpha} \frac{\partial\left(f_{i}^{n+(1 / 2)}-f_{i}^{n+(1 / 2), \mathrm{eq}}\right)}{\partial x_{\alpha}} \\
& \left.-\frac{1}{\varepsilon}\left(f_{i}^{n+(1 / 2)}-f_{i}^{n+(1 / 2), \mathrm{eq})}\right)\right]
\end{aligned}
$$

ここで $\sigma=A / \phi, \varepsilon=A / \sigma$ あるる.式(1)左辺第 2 項 の空間微分には 4 次の中心差分に 3 次の数值粘性項を 加えた次式による離散化を行う。

$$
\left.\left(c_{\alpha}-V_{\alpha}\right) \frac{\partial f}{\partial x_{\alpha}}\right|_{j}=\left(c_{\alpha}-V_{\alpha}\right)
$$




$$
\begin{aligned}
& \times \frac{f_{j-2}-8 f_{j-1}+8 f_{j+1}-f_{j+2}}{12 \Delta x_{\alpha}} \\
& +\varkappa\left|c_{\alpha}-V_{\alpha}\right| \frac{f_{j-2}-4 f_{j-1}+6 f_{j}-4 f_{j+1}+f_{j+2}}{12 \Delta x_{\alpha}}
\end{aligned}
$$

$j$ は格子番号, $\varkappa$ は数值粘性係数である.

軸対称計算領域の断面を図 3 に示す。計算領域は右 からトンネル入口空間, トンネル内部, トンネル出口 空間で構成され，図 3 中にトンネル半径で基準化した 各部分の寸法を示す. 空間の寸法は境界からの反射波 が解析詨象の現象に影響しない大きさである。列車は 図の右から左に一定速度 $U$ で進行する. 太心破線は 移動格子と静止格子の境界を示し, 列車を含むトンネ ル内とその延長部分に移動格子を適用し,トンネル壁 から上の部分は静止格子とする，図 4 に移動格子と静 止格子の接合を示す，実線は移動格子，破線は静止格 子を表し，中間に接合部がある。列車の進行とともに 図 4(a) から (b)のように接合部が変形するが, 変形 量が格子間隔の $1 / 2$ になると（c）のように接続点がス イッチされ，同時に全ての情報が進行方向に順送りさ れる。移動格子は時間ステップ毎にオイラー座標上で 書き換えられるが，並進のみで変形はないのでメトリ ックスの計算は最初の 1 回のみ行われる。接合部のメ トリックスは每回計算されるが, 接合部での流れの不 連続，音波の反射，屈折，散乱等は見られない.

列車およびトンネル壁面上の速度分布関数は非平衡 量外挿方式で求める。この方式は境界面上の速度分布 関数を平衡成分と非平衡成分に分け，平衡成分である 局所平衡分布関数を流れに対する境界条件から求め, 非平衡成分を近接流体の非平衡成分加ら外挿するもの

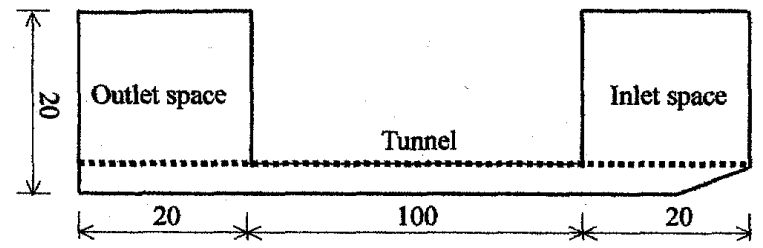

Fig. 3 Cross section of axisymmetric computational domain

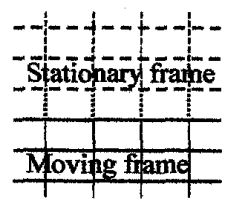

(a)

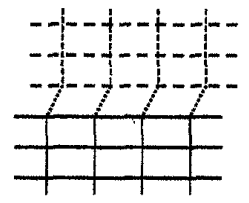

(b)

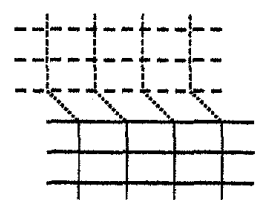

(c)
Fig. 4 Schematic diagram of grid connection
である ${ }^{(20)}$. 流れの境界条件は列車に対して粘着条件， トンネル壁には音響的に滑らかな境界を想定してす心゙ り条件，大口空間と出口空間の外側境界には自由流出 条件, 周方向は周期条件を適用する. 温度に対しては 断熱条件である。

\section{3. 計 算 結 果}

図 5 に示す円錐, 放物面, 楕円面の 3 種類の列車, ーズ形状および直線と拡大の 3 種類のトンネル入口形 状について計算を行った. Flared と表示したトンネ ル入口形状は断面を段階的に変化させたもので，棈円 面ノーズについて計算を行った。列車とトンネルの断 面積比 $A_{0} / A$ は 0.2 , 列車ノーズ部分のアスペクト比 $h / L$ は 0.2 である. 円錐形ノーズに対しては $A_{0} / A$ は 一定でLを変えることによりアスペクト比を変化ざ せた形状についても計算を行った。列車速度のマッハ 数は 0.25 であるが, 速度の影響を円錐形ノ一ズにつ いて調べた。

計算結果注領域全体の一断面の流速と圧力を一定時 間間隔ごとに出力し，圧力の時間変化をトンネル壁面 上 5 箇所とトンネル出口断面中心から $45^{\circ}$ 方向 $r / R=$ 10 の距離の出口空間内で記録した，圧力上昇 $\Delta p$ は 大気圧との差を気圧で割った無次元圧力，流速はマ ッ八数, 距離 $x$ と時間 $t$ はトンネル半径 $R$ と音速 $c_{0}$ を基準とする無次元数で表示する，xの原点はトンネ ル入口，時間の基準は列車先頭がトンネル入口に達し

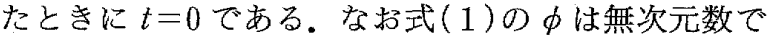
$0.25 \times 10^{-2}, A=0.99 \phi$, 式(10)の 1 は 1 である.

$3 \cdot 1$ トンネル内の流速および圧力 円錐形ノー ズの列車が進入するときのトンネル入口付近の圧力分 布抢よび渦度分布の濃淡図を図 6 に示す。図6(a)王 力の表示範囲は $0 \sim 0.03$, (b)渦度の表示範囲は -1〜1である. 圧力分布では列車前方の圧力が次第 に上昇する様子，渦度分布では車体表面とトンネル入 ロで流れのはく離による渦の形成が観測される。 cone

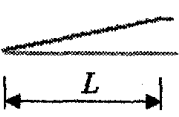

unflared

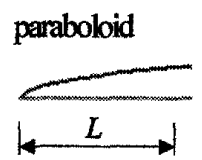

flared 1 ellipsoid

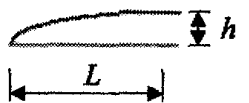

flared 2

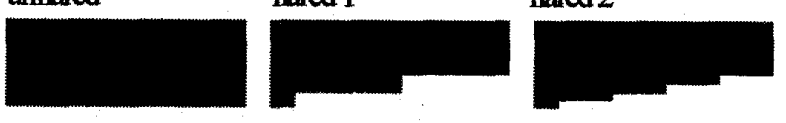

Fig. 5 Configuration of train nose profiles and tunnel portals 


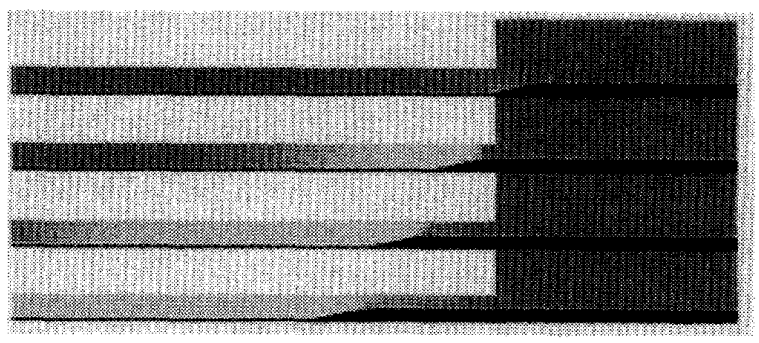

(a) Pressure rise shading

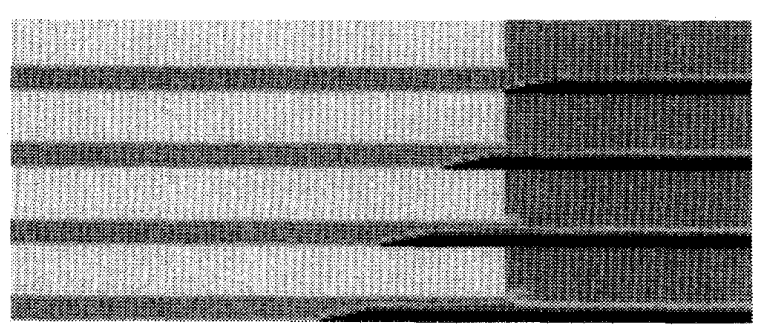

(b) Vorticity shading

Fig. 6 Flow visualization in the vicinity of tunnel entrance (cone)

図 7 にトンネル内の圧力分布の数値データを示す. 図 7(a) は壁面上の長さ方向，(b) は列車の $0.5 R$ 前 方断面, (c) は先頭加ら $5 R$ 後方断面の半径方向の変 化である. 横軸の $x-x_{0}$ は列車先頭からの相対距離, $r$ は中心軸からの距離, パラメータの $x_{0}$ は列車の先 頭位置である. 図 7 ( c )の $r<0.45$ は車体内になるの で計算值は存在しない.

トンネル内の流速分布を図 8 に示す. 図 7 と同様図 8(a) 柱長さ方向, (b) (c) 性半径方向の変化である. 図 7,8 からトンネル内の圧力と流速は半径方向に一 様であり，圧縮波は平面波として伝播していることが 分かる.ノーズ先端から压縮波の波面までの距離性列 車の進行とともに増加する. 圧力の変化は波面先端か ら急速に上昇する部分とその後の徐々に增加する部分 が観測される.前者はノーズの断面積変化部がトンネ ル入口断面を通過するとき饮発生する圧力上昇で, 後 者はトンネル内走行時の車体表面摩擦による圧力上昇 である.トンネル内の流机は車体の平行部で力向が反 転する、これはノーズがトンネルに突入するときの平 均流速の変化を示した図 9 からも明らかである。この ことから列車によって押し込まれた空気の一部はトン ネル入口から流出することが分かる.

$3 \cdot 2$ 圧縮波の発生 列車がトンネルに突入する ときに発生する圧縮波の圧力を Howe の近似線形理 論式( $4 \cdot 1$ 節参照)の適用条件 $|x| \gg \sqrt{\pi}$ 考慮して $x=-100$ 位置で計算した [図 10（a)].実線，破線，
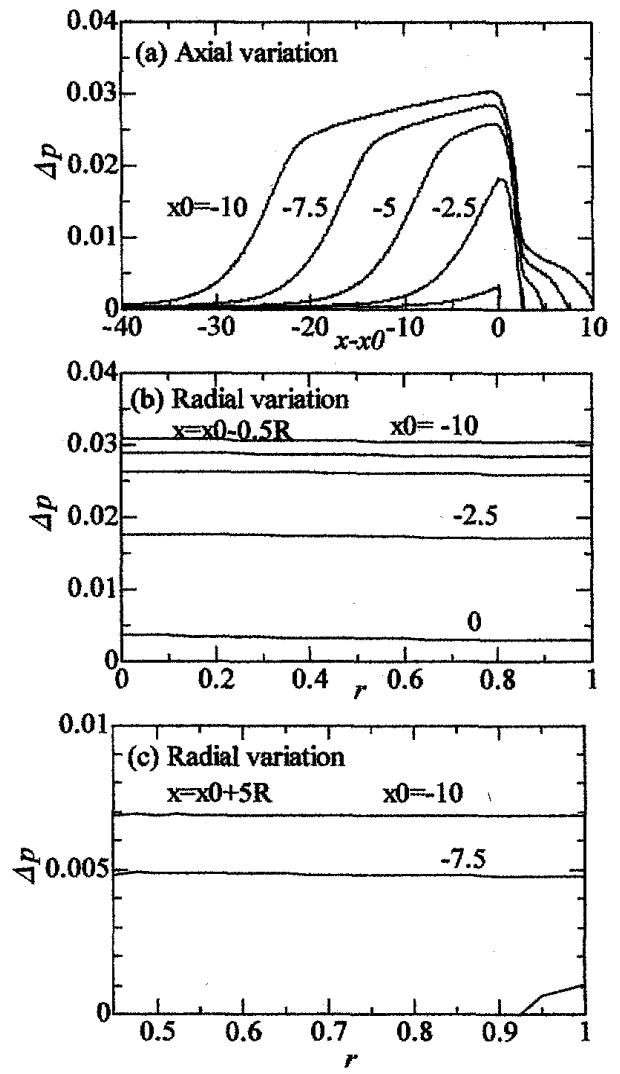

Fig. 7 Axial and radial variation of pressure rise (cone)
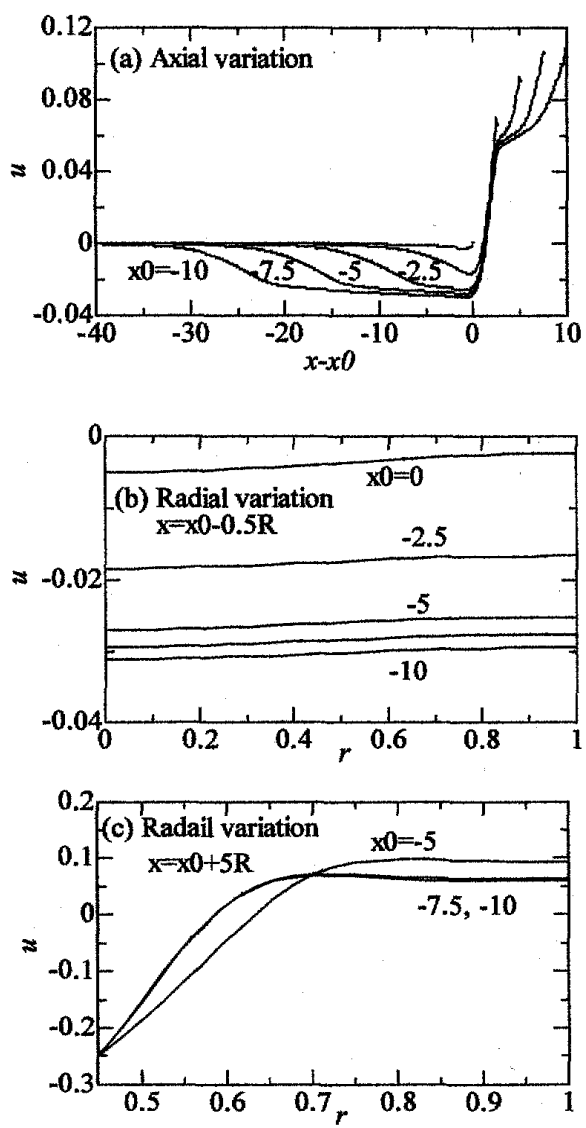

Fig. 8 Axial and radial variation of flow velocity (cone) 


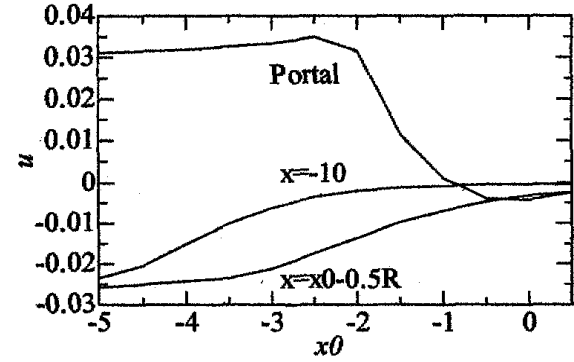

Fig. 9 Mean axial flow velocity vs. nose position (cone)
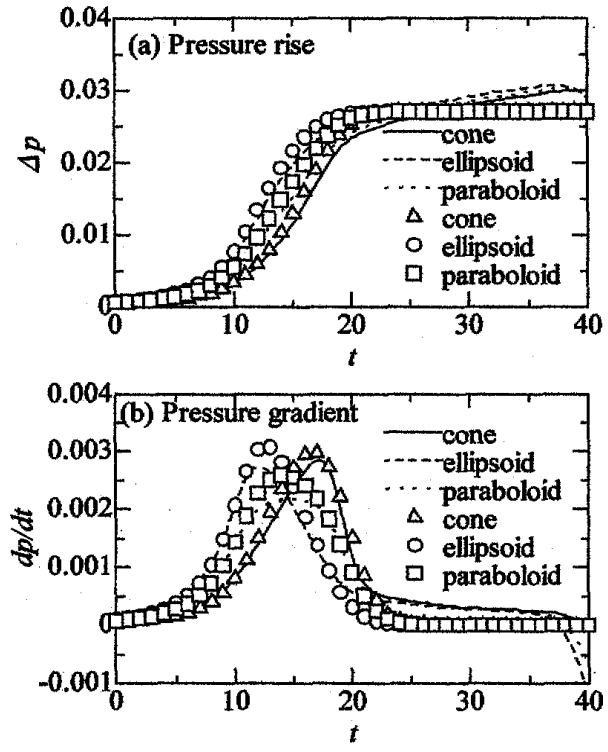

Fig. 10 Compressive wave pressure rise and pressure gradient

点線は LBM の計算結果で記号は理論式による計算值 である、円錐，杵円，放物線型のノーズ形状について 両者を比較している．出口空間の微気圧波の圧力はト ンネル出口に到達した压縮波の圧力勾配に比例するの で，上記圧力の差分から求めた圧力勾配を図 10 (b)に 示す.ノーズ形状によってピークの位置と大きさが変 化している.

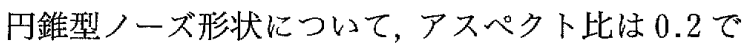
列車速度を変化させた場合と, 列車速度は 0.25 で傾 斜部分の長さを変えてアスペクト比を変化させた場合 の圧力上昇，圧力公配を図 11,12 に示す．観測位置は $x=-20$ である. 列車速度の減少とノーズ長の増加に よって波長が長くなり(波面の切立ちが緩慢になる)， 王力勾配が減少している。

トンネル入口断面を図 5 のように2 段階，4段階に 拡大したものと直線トンネルの比較を図 13 に示す. ノーズ形状は棈円型で観測位置は $x=-20$ である。 段階的に拡大したトンネルの圧力は小さな波打ちはあ
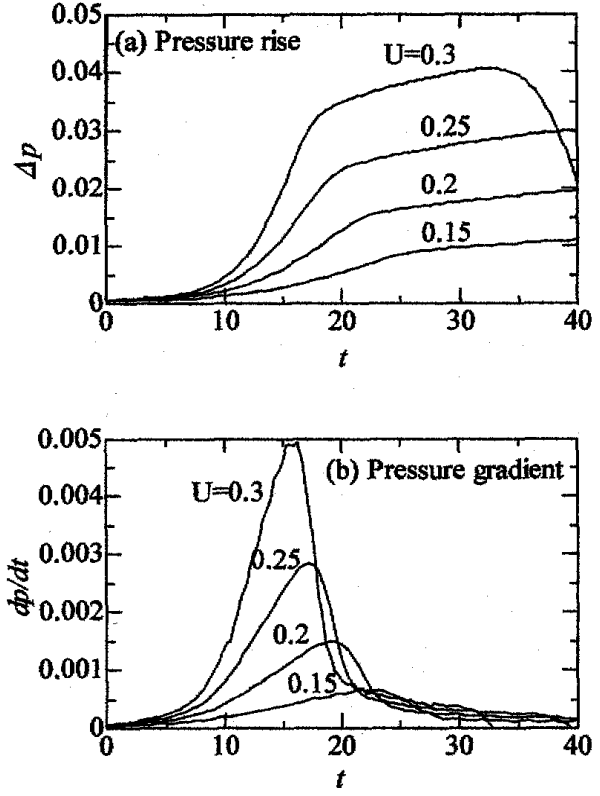

Fig. 11 Comparison of pressure rise and pressure gradient for different train speeds (cone)
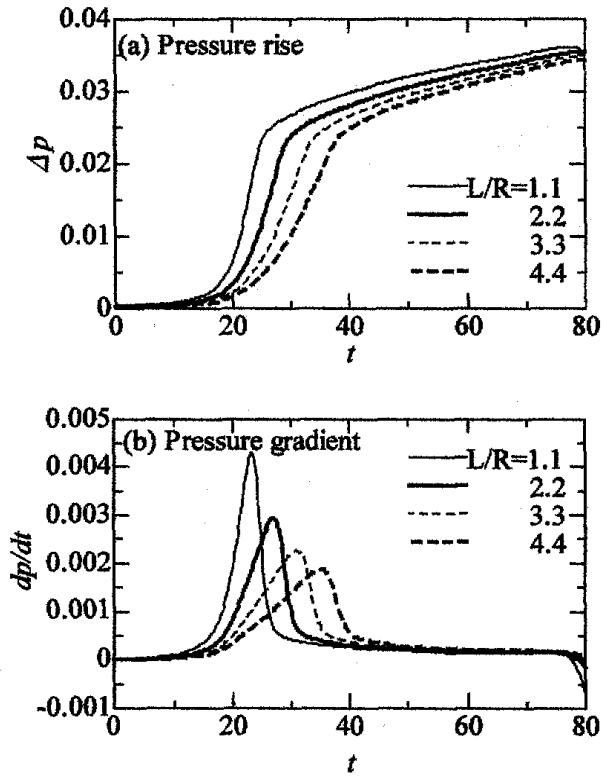

Fig. 12 Comparison of pressure rise and pressure gradient for different nose lengths (cone)

るが，ほぼ直線的に上昇している，これに封応して圧 力勾配の顕著なピークがなくなっている。

\section{$3 \cdot 3$ 圧縮波のトンネル内伝播と微気圧波の放射}

圧縮波の伝播過程での変化を調べるためにトンネル内 の各点で観測した压力上昇と圧力勾配を図 14 に示す. ノーズ形状は円錐形である。各観測点の $\Delta p$ は時間経 過とともに増加するが, $x=-10$ の $t>40$ で低下する のは列車の到達によるものである．また， $x=-90$ で の低下はトンネル出口からの反射波の影響による。 
$d p / d t$ の最大值はトンネル入口からの距離とともに増 加しており，波面が切立っていることが分かる.

圧力勾配の最大值に対する列車速度とノーズのアス ペクト比の影響を調べた結果を図15に示す。図 15（a ）は速度，（b）はアスペクト比を変えた場合であ る.両ケースともトンネル入口での最大勾配が大きい 程, その後の増加割合が大きくなっている.このこと から初期の圧縮波が急峻であればあるほど,より短い 距離で衝撃波になると推察される.

トンネル入ロを 2 段階に拡大した場合について圧力
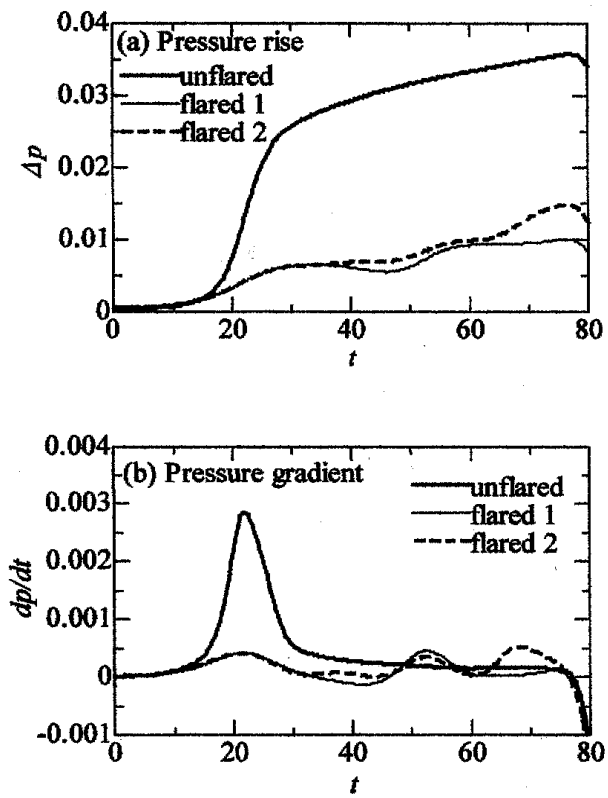

Fig. 13 Comparison of pressure rise and pressure gradient for different tunnel portals (ellipsoid)
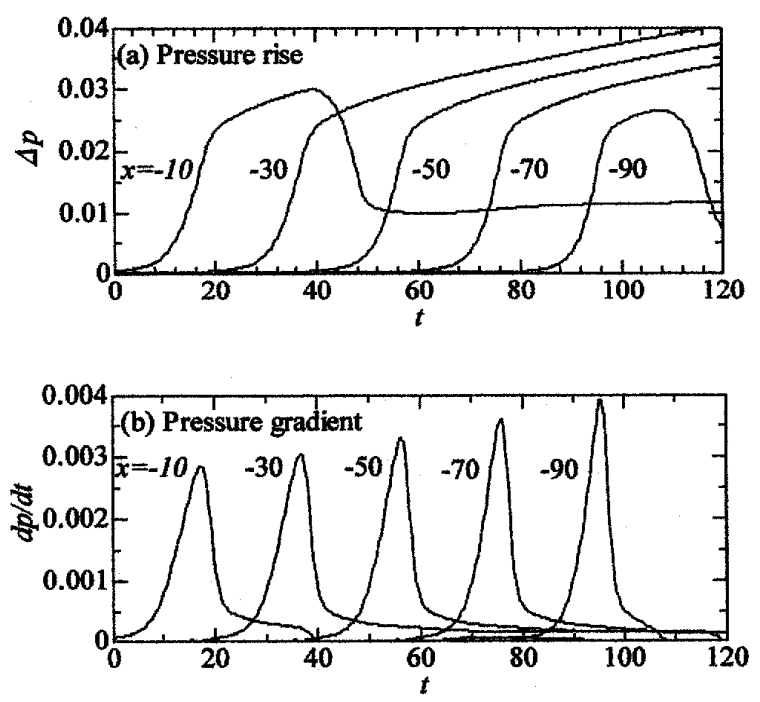

Fig. 14 Pressure rises and pressure gradients along the tunnel (cone)
勾配の最大值の変化を図 16 に示す。この場合, 初期 波の勾配が小さいので伝播過程での変化は見られな w.

トンネル出口から放射される微気圧波の圧力を $45^{\circ}$ 方向 $r=10$ の位置で観測した結果を図 17 に示す。実 線は観測值で破線はトンネル出口 $x=-90$ におる 压縮波の压力勾配から求めた值 $(4 \cdot 3$ 節参照)である。
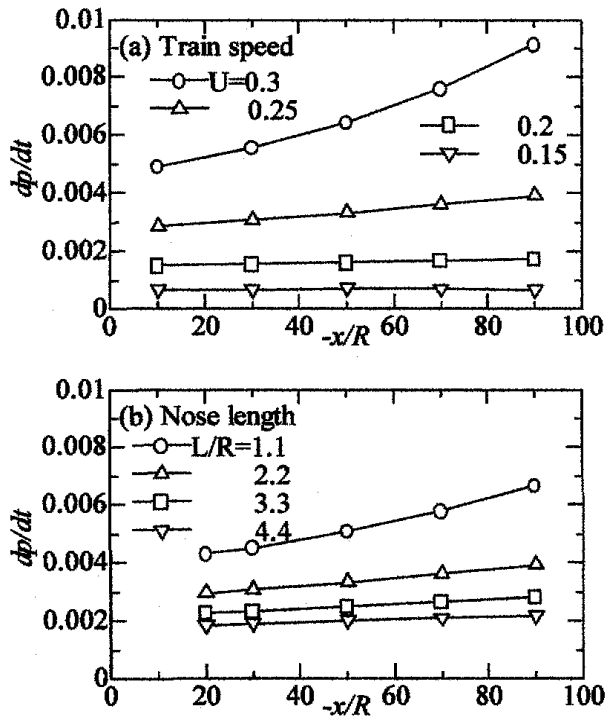

Fig. 15 Pressure gradients as functions of distance for various train speed and nose lengths (cone)

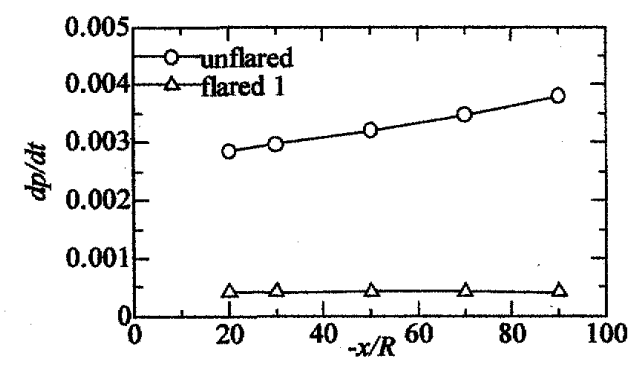

Fig. 16 Pressure gradients as a function of distance from tunnel entrance for unflared and flared portals (ellipsoid)

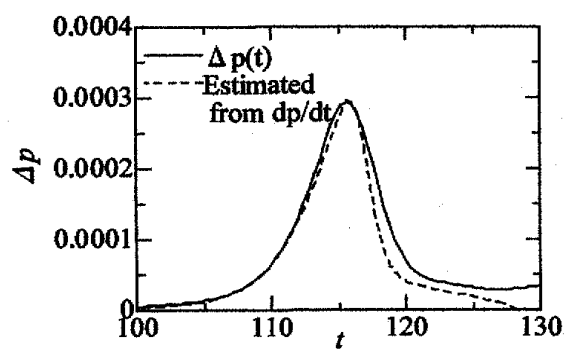

Fig. 17 Comparison of micro-pressure waveform (cone) 


\section{4. 考 察}

$4 \cdot 1$ 近似線形理論との比較 円筒形トンネルに 軸対称の列車が進入するときに発生する圧縮波の近似 線形理論式が Howeによって導かれている，圧力は 車体表面に分布した単極子, 双極子音源とトンネルの 伝播特性を表すグリーン関数から求められ，トンネル 入口近くの圧力上昇が次式より計算される(9).

$$
\begin{aligned}
p \approx & \frac{\rho_{0} U^{2}}{A\left(1-M^{2}\right)}\left(1+\frac{A_{0}}{A}\right) \\
& \times \int_{-\infty}^{\infty} \frac{\partial A_{T}}{\partial x}(x+U[t]) \frac{\partial \varphi^{*}}{\partial x}(x) d x
\end{aligned}
$$

ここで $\rho_{0}, U, M, A$ 怯それぞれ大気密度, 列車速度, マッハ数, トンネル断面積である. $A_{T}, A_{0}$ は車体の ノ一ズと平行部分の断面積で， $A_{T}$ は先端からの距離 の関数である。[t] は遅れ時間 $t$ あ $l / c, l$ はトンネル 大口から観測点までの開口端補正を含む距離である。 $\varphi^{*}(x)$ はトンネル入口から流出する単位速度渦なし流 れの速度ポテンシャルで, フランジなし円筒ダクトに 対して次の理論式が示されている(8).

$$
\begin{aligned}
& \frac{\partial \varphi^{*}}{\partial x}(x)=\frac{1}{2}-\frac{1}{2 \pi} \int_{0}^{\infty} I_{0}\left(\frac{\xi r}{R}\right)\left[\frac{2 \dot{K}_{1}(\xi)}{I_{1}(\xi)}\right]^{1 / 2} \\
& \times \sin \left\{\xi\left[\frac{x}{R}+Z(\xi)\right]\right\} d \xi \cdots \cdots \cdots \cdots \cdots \cdots \\
& Z(\xi)=\frac{1}{\pi} \int_{0}^{\infty} \ln \left[\frac{K_{1}(\mu) I_{1}(\mu)}{K_{1}(\xi) I_{1}(\xi)}\right] \frac{d \mu}{\mu^{2}-\xi^{2}} \cdots \cdots
\end{aligned}
$$

$r$ は中心軸加らの距離, $I_{0}, I_{1}, K_{1}$ は変形ベッセル関 数 ${ }^{(21)}$ である。

図 10 に記号で示したデータは上式を無次元化した 式による計算結果である。 $t<20$ では LBM と線形理 論の值はよく一致している. $t>20$ の LBM の結果で は車体表面摩擦の影響により $\Delta p$ は徐々に増加する が, 線形理論では摩擦の影響は考慮されていないので 両者は一致しない. 図 10 に示した压力勾配 $d p / d t の$ 値も放物面ノーズの最大値付近を除いて両者はほほ一 致している。

次にトンネル入口断面を段階的に拡大した場合につ いて LBM と線形理論の計算値を比較する. 式(12)の 速度ポテンシャル $\varphi^{*}(x)$ にはラプス方程式の数值 解を用いる.トンネル入口形状 flared 2 に対する数値 解のトンネル中心軸上の $\partial \varphi^{*} / \partial x$ の值を図 18 に, 楕円 ノーズ形状について計算した $x=-10$ における圧力 上昇の比較を図 19 に示す。この場合も LBM と線形 理論の計算值はよく一致している.

$4 \cdot 2$ 非線形波動伝播理論との比較 $\quad 3 \cdot 3$ 節に示 した圧縮波の非線形性による波形の変形を管内一次元 波動に対するBurgers 方程式の解で検証する．Bur-

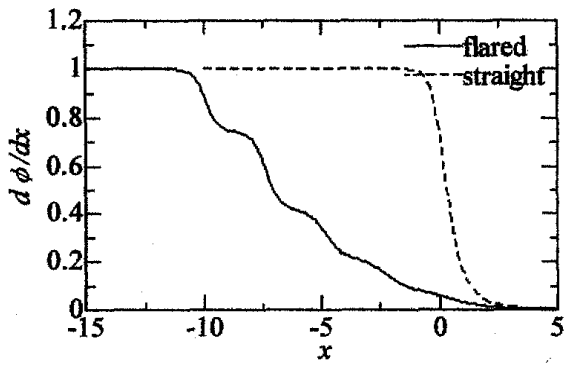

Fig. 18 Derivative of velocity potential for flared portal

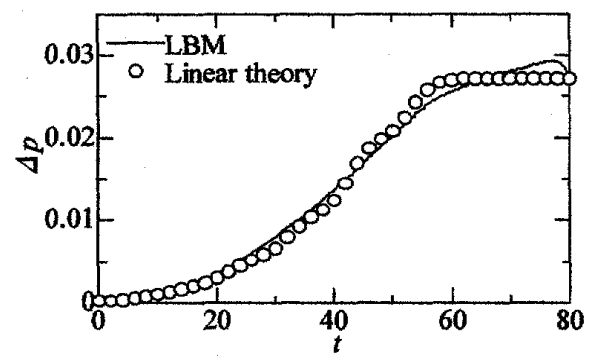

Fig. 19 Numerical predictions for flared portal (ellipsoid)

gers 方程式は初期波形が正弦波の場合は級数和で表 される理論解が存在するが(16), 任意の初期波形の場合 は数值的に解を求める必要がある(22).この数值解法 は無次元化 Burgers 方程式

$$
\frac{\partial P}{\partial \sigma}=A P \frac{\partial P}{\partial \theta}+\frac{1}{\Gamma} \frac{\partial^{2} P}{\partial \theta^{2}}
$$

に $P(\sigma=0, \theta)$ の初期值を与光て $P(\sigma+\Delta \sigma, \theta+\Delta \theta)$ を順次計算するものである.ここで $P=p / p_{0}, \sigma=$ $x / \bar{x}, \bar{x}$ : 衝撃波形成距離, $\theta=\omega \tau, \tau$ : 遅れ時間, $\Gamma$ : Gold'burg 数, $A$ ：係数である．詳細は省略するが計 算には非線形項と拡散項を分離して計算する部分ステ ップ法のアルゴリズム ${ }^{(22)}$ を用いる。近似線形理論と の比較 $(3 \cdot 2$ 節)に用いた $x=-10$ におけるLBM の波 形を基点の值として $x=-50$ ，一 -90 に打沙波形を計 算した結果と LBM 計算值との比較を図 20 に示す. $x=-90$ な゙の範囲で LBM と Burgers方程式の計 算結果は一致している。なお，基点の選び方が LBM 妥当性の検証に影響することはない。詳しくは文献 (16) を参照されたい.

$4 \cdot 3$ トンネル微気压波の放射微気压波の音王 はトンネル出口に到達した圧縮波の圧力公配に比例す る単極子音源からの放射音圧として次式から求められ $ろ^{(8)}$.

$$
p_{\text {micro }} \approx \frac{\alpha A}{2 \pi c_{s} r} \frac{\partial p}{\partial t}\left(t-\frac{r}{c_{s}}\right)
$$



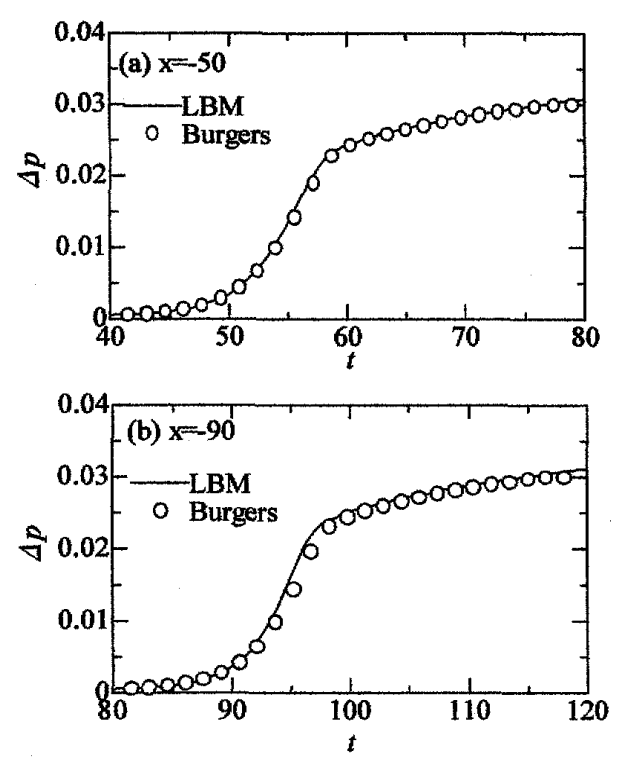

Fig. 20 Comparison of LBM and Burgers predictions

ここで $A$ はトンネル断面積， $\alpha$ は出口開口端の透 過係数を表し $O(1)$ の定数である. 図 17 の圧力勾配 からの推定値は式(15)に扔いて $\alpha \approx 0.8$ として計算し た値である. パルスの立下りの部分を除いて観測波形 とほほ一致している.

\section{5. 結語}

本研究では高速列車がトンネルに突入するときに発 生する圧縮波と微気圧波の計算に差分格子ボルツマン 法を適用することを提案し，円筒型トンネルに突入す る種々のノーズ形状の列車について詳細な計算を行つ た. その結果, トンネル入口付近の初期波形はノーズ の断面が変化する部分に単極子, 双極子音源を分布さ せる近似線形理論による計算值とほほ一致することが 分かった。また，トンネル内波動の非線形作用による 波形の切り立ち現象は Burgers 方程式の数值解と一 致することを示した．この波形の切り立ちは初期波の 圧力公配によって変わり，ノーズ形状とトンネル入口 形状の改善による初期波圧力勾配の低隇はトンネル出 口の微気压波放射に対して初期圧力勾配の低減々非線 形作用による急峻化の緩和の相乗効果がある.

このように格子ボルッマン法はトンネル圧縮波の発 生と伝播を同時に精度よく計算することができ, 複雑 な現象の解明に有効であることが分かった。

\section{謝辞}

本研究の内容について財団法人鉄道総合技術研究所 の前田達夫博士および関係者の皆様から多くの助言を 頂いたことに感謝の意を表す。

\section{文献}

(1) Ozawa, S., Morimoto, Y., Maeda, T. and Kinoshita, M., Investigation of the Pressure Wave Radiated from a Tunnel Exit (in Japanese), Railway Technical Research Report, No. 1023 (1976).

(2) Ozawa, S., Studies of Micro-Pressure Wave Radiated from a Tunnel Exit (in Japanese), Railway Technical Research Report, No. 1121 (1979).

(3) Fukuda, T., Ozawa, S., Iida, M., Takasaki, T. and Wakabayashi, Y., Distortion of Compression Wave Propagation through Very Long Tunnel with Slab Tracks, JSME International Journal, Ser. B, Vol.49, No. 4 (2006), pp. 1156-1164.

(4) Aoki, T., Matsuo, K., Hidaka, H., Noguchi, Y. and Morihara, S., Attenuation and Distortion of Propagating Compression Wave in a High-Speed Railway Model and Real Tunnels, Proceedings of the International Symposium on Shock Waves, (1995), pp. 347-352.

(5) Sugimoto, N., Propagation of Non-Linear Acoustic Waves in a Tunnel with an Array of Helmholtz Resonators, Journal of Fluid Mechanics, Vol. 244 (1992), pp. 55-78.

(6) Sugimoto, N., Sound Field in a Tunnel Generated by a Traveling High Speed Train, Theoretical Computational Acoustics, No. 1 (1994), pp. 45-56.

(7) Sugimoto, N. and Ogawa, T., Acoustic Analysis of the Pressure Field in a Tunnel, Generated by Entry of a Train, Proceedings of the Royal Society of London, A 454 (1998), pp. 2083-2112.

(8) Howe, M. S., The Compression Wave Produced by a High-Speed Train Entering a Tunnel, Proceedings of the Royal Society of London, A 454 (1998), pp. 15231534 .

(9) Howe, M. S., Iida, M., Fukuda, T. and Maeda, T., Theoretical and Experimental Investigation of the Compression Wave Generated by a Train Entering a Tunnel with a Flared Portal, Joumal of Fluid Mechanics, Vol. 425 (2000), pp. 111-132.

(10) Mashimo, S., Nakatsu, E., Aoki, T. and Matsuo, K., Attenuation and Distortion of Compression Wave Propagating in a High-Speed Railway Tunnel, JSME International Journal, Ser. B, Vol. 40, No. 1 (1997), pp. 51-57.

(11) Miyachi, T., Fukuda, T. and Ozawa, S., Numerical Simulation of Distortion of Compression Wave Propagating Through a Tunnel with Ballasted Track (in Japanese), RTRI REP, Vol.21, No. 3 (2007), pp. 29-34.

(12) Chen, S. and Doolen, G. D., Lattice Boltzmann Method for Fluid Flows, Annual Review of Fluid Mechanics, Vol. 30 (1998), pp. 329-364.

(13) Tsutahara, M., Kataoka, T., Shikata, K. and Takada, N., New Model and Scheme for Compressible Fluids of the Finite Difference Lattice Boltzmann Method and Direct Simulation of Aerodynamic Sound, Computers and Fluids, No. 37 (2008), pp. 79-89.

(14) Tamura, A., Tsutahara, M., Kataoka, T., Aoyama, T. and Yang, C., Numerical Simulation of Two-Dimensional Blade-Vortex Interactions Using Finite Difference Lattice Boltzmann Method, AIAA Journal, Vol. 46, No. 9 (2008), pp. 2235-2247.

(15) Kang, H. and Tsutahara, M., An Application of the Finit Difference-Based Lattice Boltzmann Model to 
Simulating Flow-Induced Noise, International Journal for Numerical Method in Fluids, Vol. 53 (2007), pp. 629-650.

(16) Akamatsu, K., Tamura, A., Kataoka, T. and Tsutahara, M., A Numerical Simulation for Finite Amplitude Sound Waves Using Finite Difference Lattice Boltzmann Method (in Japanese), Transactions of the Japan Society of Mechanical Engineers, Series B, Vol. 75, No. 752 (2009), pp. 718-723.

(17) Hirt, C. W., Amsden, A. A. and Cook, J. L., An Arbitrary Lagrangian-Eulerian Computing Method for All Flow Speeds, Journal of Computational Physics, Vol. 14 (1974), pp. 227-253.

(18) Tamura, A. and Tsutahara, M., Direct Simulation of Acoustic Waves Emitted from Moving Bodies by the Finite Difference Lattice Boltzmann Method, AIAA
Paper, 2006-2489 (2006).

(19) Tsutahara, M., Takada, N. and Kataoka, T., Lattice gas and Lattice Boltzmann Methods (in Japanese), (1999), pp. 99-108, Corona-sha.

(20) Guo, Z. L. et al., Non-Equilibrium Extrapolation Method for Velocity and Pressure Boundary Conditions in the Lattice Boltzmann Method, Chinese Physics, Vol. 11, No. 4 (2002), pp. 366-374.

(21) Moriguchi, S., Udagawa, K. and Hitotsumatsu, S., Mathematical formula III (in Japanese), (1960), p. 170, Iwanami.

(22) Cleveland, R. O. et al., Time-Domain Modeling of Finite-Amplitude Sound in Relaxing Fluids, The Jour nal of the Acoustical Society of America, Vol. 99, No. 6 (1996), pp. 3312-3318. 